\title{
ANALISIS RASIO LIKUIDITAS, RASIO PROFITABILITAS DAN SALES GROWTH PRA DAN PASCA BERLAKUNYA UNDANG-UNDANG BADAN PENYELENGGARA JAMINAN SOSIAL
}

\author{
Stevany Febreany \\ Fakultas Ekonomi Universitas Krisnadwipayana \\ Jalan Unkris Jatiwaringin \\ Jakarta Timur \\ email: stevany.febry@gmail.com
}

\begin{abstract}
The National Health Insurance Program is a mandatory social health insurance. The problem is experienced by pharmaceutical companies where product prices in the era of National Health Insurance have been determined by the government making the price below the company's production costs plus the deficit experienced by the Social Security Administering Agency (BPJS) resulting in companies having to operate on a low profit and low margin. The purpose of this study is to identify financial conditions in the pre and post era of the National Health Insurance. The research method used is descriptive quantitative research method with financial ratio comparison analysis tools, namely liquidity ratios calculated through the cash ratio, profitability ratios calculated through net profit margins and sales growth in the financial statements of PT Hexpharm Jaya Laboratories from 20092013 and 2014- 2018. The results showed that the liquidity ratio calculated by cash ratio and profitability ratio calculated by net profit margin was lower after post-National Health Insurance compared to the era before National Health Insurance. Sales growth experienced growth after the National Health Insurance.
\end{abstract}

Keywords: National Health Insurance, Liquidity, Profitability, Sales Growth

\section{PENDAHULUAN}

Pemerintah Indonesia sangat memperhatikan pelayanan kesehatan dari sejak dahulu, terbukti dari pertama kali pelayanan kesehatan diberikan kepada pegawai negeri sipil dan anggota keluarganya. Pada tahun 1968, pemerintah membentuk badan yang bertugas untuk para pegawai dan para pensiunan berserta anggota keluarga dalam pemeliharaan kesehatan yang dinamai Badan Penyelenggara Dana Pemeliharaan Kesehatan (BPDPK). Selanjutnya pemerintah menerbitkan kembali peraturan dengan memperluas penerima pelayanan kesehatan selain pegawai negeri yaitu veteran, perintis kemerdekaan serta pensiunan dan dinamakan Perum Husada Bakti (PHB). Tahun 1992, pegawai BUMN mendapatkan pelayanan jaminan kesehatan yang sama dengan program Asuransi Kesehatan Komerisal, karena itu pemerintah membentuk PT Askes (Persero). Selain itu, pemerintah membuat jaminan kesehatan untuk warga Negara Indonesia yang belum masuk dalam Jamkesmas, ataupun asuransi lainya yang disebut dengan Jaminan Kesehatan Masyarakat Umum (PJKMU).

Penelitian sebelumnya yang dilakukan oleh Dyah bersama Sakir pada tahun 2019 menunjukkan hasil penelitian bahwa kebijakan Universal Health Coverage (UHC) adalah masalah kebijakan kesehatan yang penting di antara Negara-negara ASEAN. Maka dari itu, Indonesia memiliki keinginan yang ingin diwujudkan pada tahun 2019 yaitu 
untuk menuju Universal Health Coverage (UHC). Bukti yang sudah terlihat adalah dengan mengeluarkan peraturan mengenai Badan Penyelenggara Jamian Sosial (BPJS) dalam Undang-undang nomor 24 Tahun 2011 yang memiliki tujuan untuk menyatukan berbagai badan penyelenggara sosial yang sebelumnya. Dengan adanya beberapa bentuk program jaminan sosial, maka biaya-biaya kesehatan dan fasilitasfasilitas pelayanan kesehatan menjadi bermacam-macam sehingga sulit dikendalikan, dan banyak warga Negara Indonesia yang belum menerima manfaat dari berbagai jaminan kesehatan tersebut.

Program Jaminan Kesehatan Nasional (JKN) merupakan program yang bersifat wajib (mandatory) yang dikeluarkan oleh Pemerintah untuk membayar iuran atau pemerintah yang menanggung iurannya agar kebutuhan akan pelayanan kesehatan terpenuhi. Badan Penyelenggara Jaminan Sosial (BPJS) memberikan dampak positif kepada animo masyarakat Indonesia untuk peduli terhadap kesehatan dengan semakin mudahnya memperoleh akses pengobatan yang didukung dengan hasil penelitian sebelumnya yang pernah dilakukan pada tahun 2019 oleh Yusriadi menunjukkan inovasi pada layanan kesehatan melalui program BPJS menggambarkan peningkatan kepuasan peserta dan fasilitas.

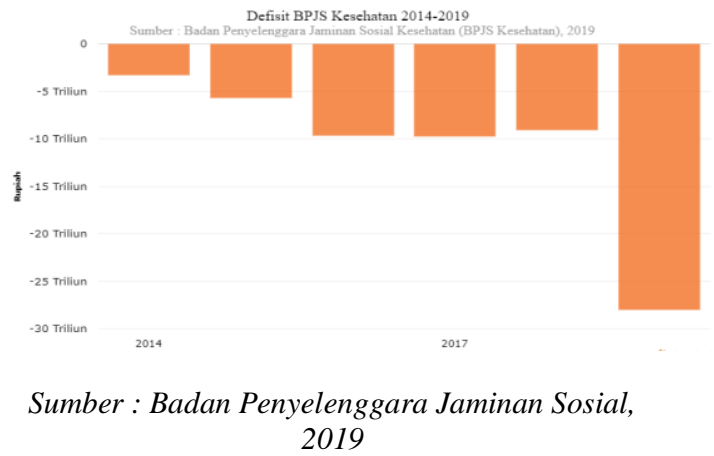

Gambar 1. Defisit BPJS kesehatan tahun 2014-2019

Tidak hanya berdampak pada masyarakat, tetapi berdampak pula pada BPJS yaitu banyaknya Peserta Bukan Penerima Upah (PBPU) yang mendaftar dan membayar premi hanya pada saat sakit dan berhenti membayar premi setelah memperoleh layanan kesehatan dengan kata lain manfaat yang ditetapkan belum sesuai dengan kemampuan pendanaan program yang berakibat underfunded program dan berpengaruh pada program jaminan kesehatan nasional. Terlihat dari gambar 1 menunjukkan trend defisit dari tahun 2014-2019 pada Badan Penyelenggara Jaminan Sosial (BPJS).

Tahun 2014, defisit mencapai 3,3 triliun rupiah dimana tahun 2015 defisit semakin bertambah menjadi 5,7 triliun rupiah, sama halnya di tahun 2016, defisit makin meningkat dengan lonjatan yang cukup tinggi yaitu mencapai angka 9,7 triliun rupiah, naik menjadi 9,8 triliun pada tahun 2017. Pada tahun 2018, angka defisit menurun sedikit dibanding tahun 2017 dan 2016 yaitu menjadi 9,1 triliun, meski begitu rata-rata setiap tahun defisit mengalami kenaikan.

Dengan BPJS yang mengalami defisit dari tahun ke tahun, maka pembayaran BPJS kepada rumah sakit akan mundur dan tidak tepat waktu 
sehingga berdampak pada cash flow perusahaan khususnya perusahaan farmasi. Apabila rumah sakit tidak dapat membayar kepada perusahaan secara tepat waktu maka perusahaan harus berupaya keras untuk mengelola ketersediaan kas perusahaan yang mana ketersediaan kas menjadi salah satu aset untuk mendanai operasional bisnis perusahaan yang akan berpengaruh pada ketersediaan obat di lapangan. Penelitian yang dilakukan oleh Muhammad Farham Madina dengan judul pembahasan Analisis Kinerja Keuangan Perusahaan Asuransi di Indonesia sebelum dan sesudah adanya Undang-undang Badan Penyelenggara Jaminan Sosial (BPJS) menunjukkan rasio likuiditas aset memberikan reaksi negatif terhadap Undang-undang BPJS. Hasil dari penelitian ini mengalami penurunan dari yaitu 2,03 menjadi 2,14 sesudah undang-undang BPJS diselenggarakan.

\begin{tabular}{|c|c|c|c|c|}
\hline OBAT GENERIK & $\mathrm{RP}$ & \begin{tabular}{|l|} 
ORIGINATOR \\
\end{tabular} & $\mathrm{RP}$ & SELISIH \\
\hline Paracetamol $500 \mathrm{mg}$ & 132 & Panadol & 260 & $2.0 x$ \\
\hline Metformin $500 \mathrm{mg}$ & 186 & Glucophage & 1,500 & $8.2 x$ \\
\hline Amoxycillin & 450 & Amoxil & 4,000 & $8.7 x$ \\
\hline Asam Mefenamat $500 \mathrm{mg}$ & 165 & Ponstan & 2,400 & $14.6 x$ \\
\hline Acyclovyr $200 \mathrm{mg}$ & 610 & Zoviraz & 10,100 & $16.6 x$ \\
\hline Levofloxacyn $500 \mathrm{mg}$ & 1,442 & Cravit & 38,600 & $26.8 x$ \\
\hline Captopril $24 \mathrm{mg}$ & 175 & Capoten & 7,990 & $46.5 x$ \\
\hline Ciprofloxacin & 325 & Ciproxin & 28,900 & $85.0 x$ \\
\hline
\end{tabular}

Gambar 1 Perbedaan harga obat generik dan originator

Sebelum Era Jaminan Kesehatan Nasional, pengadaan obat di rumah sakit dilakukan dengan cara negosiasi oleh perusahaan dengan harga obat yang telah ditentukan oleh perusahaan.
Terlihat dari Gambar 2, obat originator dan obat generik walaupun memiliki kandungan serta khasiat yang sama tetapi memiliki perbedaan pada harga yang dijual. Karena itu, pemerintah mengeluarkan sistem pengadaan obat yang dilakukan dengan prosedur $E$ purchasing di katalog online atau sistem E-catalogue. Sistem pengadaan obat yang baru pada era JKN memberi dampak positif yaitu lebih efektif dan efisien bagi pemerintah karena lebih memudahkan dalam pemilihan produk, dan harga serta spesifikasinya sudah jelas. Harga yang terdapat dalam sistem merupakan harga produk yang sudah termasuk dengan biaya distribusi produk dan harga yang sudah include pajak serta dihitung dalam satuan terkecil. Selain itu, pengadaan obat saat ini menjadi lebih transparan dan dapat meminimalisasi penyimpangan.

Industri farmasi tidak setuju dengan pemerintah yang telah menetapkan harga jual obat generik. Karena, harga obat-obatan pada era JKN ini masih dibawah biaya produksi perusahaan yang mengakibatkan banyak industri farmasi tidak mampu memproduksi obat yang biasanya diproduksi karena margin keuntungan kecil. Selain itu, perusahaan dituntut mendistribusikan obat yang dijual ke daerah-daerah terpencil yang mengakibatkan meningkatnya beban distribusi. Sehingga, perusahaan harus beroperasi secara low price dan low margin. Menurunnya harga jual obat dan meningkatnya beban distribusi akan berpengaruh pada tingkat profit perusahaan.

Pada penelitian sebelumnya yang dilakukan oleh Yuyun Suhartiyas Implementasi Jaminan Kesehatan 
Nasional menghasilkan nilai rasio profitabilitas yang diukur melalui profit margin pada RS X. Mojokerto lebih tinggi pada saat sesudah implementasi Jaminan Kesehatan Nasional, saat sebelum implementasi Jaminan Kesehatan Nasional kondisi rumah sakit yang mengalami kerugian yang ditandai dengan profit margin rumah sakit minus. Penelitian ini didukung dengan penelitian lainnya yaitu dari Universitas Respati Indonesia yang menghitung profit margin pada perusahaan asuransi yang terdapat di BEI dan menghasilkan bahwa profit margin pada implementasi JKN yaitu dari tahun 2014-2018 menurun dibandingkan dengan sebelum implementasi.

Tidak hanya berpengaruh pada cash flow perusahaan, profit perusahaan, tetapi pada Era Jaminan Kesehatan Nasional berpengaruh pula pada tingkat penjualan perusahaan. Karena, terlihat dari gambar 3, jumlah permintaan obat dari tahun ke tahun meningkat serta jenis obat yang dibutuhkan semakin beragam.

\begin{tabular}{|c|c|c|c|c|c|}
\hline \multirow{2}{*}{ JUMLAHSEDIAAN OBAT } & \multicolumn{5}{|c|}{ TAHUN } \\
\cline { 2 - 6 } & $\mathbf{2 1 3}$ & $\mathbf{2 0 1 4}$ & $\mathbf{2 0 1 5}$ & $\mathbf{2 0 1 6}$ & $\mathbf{2 1 7}$ \\
\hline FORNAS & $\mathbf{( D 0 1 N )}$ & $\mathbf{9 2 3}$ & $\mathbf{9 3 0}$ & $\mathbf{1 0 1 8}$ & 1031 \\
\hline $\begin{array}{l}\text { Sumber : FORNAS Kemenkes dan E-Catalogue } \\
\text { LKPP }\end{array}$
\end{tabular}

Gambar 2 Jumlah permintaan persediaan obat

Terlihat pada penelitian yang dilakukan oleh Rina Wahyu Wijayani dengan judul penelitian Dampak Implementasi Program Jaminan Kesehatan Nasional (JKN) Terhadap Kinerja Keuangan Rumah Sakit Vertikal Kementerian Kesehatan total pendapatan yang diterima setelah implementasi program Jaminan Kesehatan Nasional meningkat 34\% dari sebelum implementasi Program JKN. Dari hasil penelitian terdahulu, terlihat dampak JKN begitu besar terhadap tingkat kesehatan di Indonesia yang salah satunya berpengaruh terhadap perusahaan farmasi. Karena itu, Perusahaan harus mengetahui dampak keuangan serta tingkat penjualan dengan adanya implementasi Jaminan Kesehatan Nasional saat ini.

Berdasarkan permasalahan yang dialami oleh perusahaan farmasi mengenai harga produk pada era Jaminan Kesehan Nasional telah ditentukan oleh pemerintah membuat harga tersebut dibawah biaya produksi ditambah dengan deficit yang dialami oleh BPJS mengakibatkan banyak perusahaan yang beroperasi secara low profit dan low margin dari hasil penelitian-penelitian terdahulu diatas, maka penulis tertarik untuk melakukan penelitian dengan mengambil judul penelitian "Analisis Rasio Likuiditas, Rasio Profitabilitas dan Sales Growth Pra dan Pasca Berlakunya Undang-undang Badan Penyelenggara Jaminan Sosial (Studi Kasus pada PT Hexpharm Jaya Laboratories Periode 20092013 dan Periode 2014-2018)".

\section{KAJIAN TEORI}

\section{Badan Penyelenggara Jaminan Sosial (BPJS)}

Hak jaminan kesehatan berupa pelayanan kesehatan sudah dimiliki oleh setiap warga Negara Indonesia seperti yang telah tercantum pada Undang-undang Dasar Negara Republik Indonesia Tahun 1945: 
UUD 1945 Pasal 28H ayat 1:

"Setiap orang berhak hidup sejahtera lahir dan batin, bertempat tinggal, dan mendapatkan lingkungan hidup yang baik dan sehat serta berhak mendapatkan pelayanan kesehatan".

UUD 1945 Pasal 34 ayat 3:

"Negara bertanggung jawab atas penyediaan fasilitas pelayanan kesehatan dan fasilitas pelayanan umum yang layak".

Penyelenggara pemeliharaan kesehatan untuk seluruh masyarakat Indonesia beserta anggota keluarga dan badan usaha lainnya yang diatur sesuai hukum yang berlaku merupakan tugas dari Badan penyelenggara jaminan sosial (BPJS). Pada zaman dahulu, di Indonesia sudah ada jaminan sosial yang pesertanya hanya pegawai negeri sipil beserta anggota keluarganya. Lalu pada 1968, Badan Penyelenggara Dana Pemeliharaan Kesehatan (BPDPK) dibentuk oleh pemerintah untuk mengatur pemeliharan kesehatan bagi pegwai negara dan penerima pensiun besrta keluarganya. Setelah itu pemerintah menerbitkan peraturan jaminan kesehatan yang disebut Perum Husada Bakti (PHB). Pada tahun 1992, PHB berganti nama menjadi PT. Askes yang menjangkau jaminan kesehatan bagi karyawan BUMN. Pada bulan januari tahun 2005, pemerintah mempercayain PT Askes (Persero) untuk melaksanakan program yang menjadikan masyarakat miskin dan tidak mampu menjadi tujuan utamanya dan dikenal dengan nama program jminan kesehatan bagi masyarakat mskin (PJKMM).

Sesuai dengan dasar hukum UUD 45 Pasal $28 \mathrm{H}$ dan UUD 45 pasal 34, tentang pelayanan kesehatan yang akan didapatkan oleh setiap orang, memperoleh persamaan dan keadilan, jaminan sosial, maka pada awal januari 2014 Jaminan Kesehatan Nasional mulai dioperasikan sebagai perubahan dari PT. Askes.

\section{Jaminan Kesehatan Nasional (JKN)}

Perlindungan serta pemeliharaan kesehatan dibutuhkan oleh setiap warga Negara Indonesia. maka dari itu, pemerintah membentuk Jaminan Kesehatan yang diatur dengan hukum yang berlaku agar setiap rakyat Indonesia memiliki kepastian terhadap kesehatan dapat hidup sehat, hidup produktif, dan hidup sejahtera. Jaminan Kesehatan Nasional memiliki prinsip yang diatur dalam Undangundang No.40 Tahun 2004:

a. Prinsip Gotong Royong, prinsip ini dapat diartikan bahwa biaya jaminan peserta JKN ditanggung bersama-sama dalam arti saling menolong karena JKN ini bersifat wajib untuk seluruh peserta. Yang belum mampu akan dibantu oleh yang mampu, yang belum sehat akan dibantu oleh yang sehat sesuai dengan tingkat pendapatan peserta.

b. Prinsip Nirlaba, berarti tujuan utama BPJS adalah memenuhi kepentingan peserta BPJS agar dapat memberikan manfaat bagi peserta, bukan untuk mencari laba/keuntungan.

c. Prinsip Keterbukaan, yang berati ada kemudahan dalam memperoleh informasi yang jeelas, lengkap dan dalam mengakses tentang informasi BPJS. 
d. Prinsip yang berkaitan dengan kecermatan, keamanan dan ketelitian dalam pengelolaan dana disebut juga prinsip kehati-hatian.

e. Prinsip yang berkaitan dengan keakuratan dan pertanggungjawaban dalam pelaksanaan program dan pengelolaan dana disebut juga prinsip akuntabilitas.

f. Prinsip yang berhubungan dengan tempat tinggal atau pekerjaan yang diberikan jaminan jika masih ada di wilayah Negara Kesatuan Republik Indonesia disebut dengan prinsip Portabilitas.

g. Prinsip yang mewajibkan seluruh warga Negara Indonesia menjadi peserta dari jaminan kesehatan nasional disebut juga prinsip kepesertaan Wajib.

h. Prinsip yang berhubungan dengan sumber dana dari iuran peserta yang merupakan titipan yang akan kembali digunakan untuk kepentingan peserta disebut dengan prinsip dana amanat.

i. Prinsip yang berhubungan dengan hasil laba yang digunakan untuk pengembngan program dan kepntingan peserta disebut dengan prinsip hasil pengelolaan dana jaminan sosial.

Berdasarkan Undang-undang No. 40 Tahun 2004, salah satu prinsip dari jamnan kesehtan nasional adalah kepesertaan yang bersifat wajib, artinya seluruh penduduk Indonesia akan menjadi peserta JKN. Pemerintah berharap di tahun 2019 seluruh penduduk Indonesia sudah terdaftar menjadi peserta jaminan kesehatan nasional, karena memiliki manfaat yaitu pelayanan kesehatan perseorangan serta pelayanan obatobatan dan bahan medis yang diperlukan dan bukan hanya pelayanan kesehatan yang berupa kuratif dan rehabilitative.

Pengadaan obat Jaminan Kesehatan Nasional (JKN) merupakan suatu proses yang ditujukan kepada perusahaan agar persediaan farmasi seperti obat-obatan atau alat kesehatan yang dibutuhkan dalam jumlah dan jenis yang telah ditentukan dapat tersedia. Pengadaan ini telah diatur pada Permenkes Nomor 48 tahun 2013 dapat dilakukan secara elektronik atau E-procurement merupakan proses penggunaaan teknologi dalam melakukan pengadaan barang atau jasa melalui transaksi elektronik yang informasinya telah jelas dalam sistem tersebut dan sudah diatur dalam undang-undang. E-purchasing adalah sebuah panduan yang terdapat pada sistem katalog elektronik dan digunakan dalam pembelian barang atau jasa yang dibutuhkan dengan cara mengakses website pada Layanan Pengadaan Secara Elektronik yang dinamakan SPSE (Sistem Pengadaan Secara Elektronik). E-tendering adalah proses upload satu kali penawaran yang dilakukan oleh penyedia barang atau jasa yang biasa dikenal sebagai perusahaan untuk dilakukan pemilihan penyedia barang atau jasa yang diikuti oleh semua penyedia barang atau jasa yang sudah terdaftar di SPSE dan selanjutnya dilakukan pemilihan penyedia tersebut secara terbuka dalam waktu yang telah ditentukan sebelumnya. E-catalogue obat merupakan daftar barang atau jasa yang dijual berdasarkan jenisnya, dan 
dijelaskan spesifikasi dari barang atau jasa tersebut dan dilampirkan harga barang atau jasa tersebut dari berbagai penyedia barang atau jasa yang dimuat dalam sistem pengadaan secara elektronik (SPSE).

Dengan adanya sistem yang baru ini terlihat dampak baiknya yaitu pada proses pengadaan barang atau jasa dalam penelitian ini yaitu obat dapat ditingkatkan transparansi dalam hal pengadaannya. Selain itu, persaingan yang dilakukan oleh antar perusahaan dapat dilakukan secara sehat atau baik serta dalam penyediaan dan proses pengadaan barang atau jasa dapat meningkatkan tingkat efektif dan efisiensinya.

\section{Rasio Likuiditas}

Rasio ini memiliki tujuan untuk menggambarkan posisi liquidity perusahaan dari periode ke periode dan dijadikan sebagai acuan untuk membuat plan selanjutnya terutama yang bersinggungan dengan planning pada kas dan utang dan untuk menganalisis dari sisi aktiva lancar dan utang lancar perusahaan dan menjadi acuan bagi perusahaan untuk memperbaiki kinerja perusahaan dengan melihat rasio likuditas (Hery, 2017:284). Kebangkrutan pada perusahaan sering terjadi, maka dari itu perusahaan harus mengantisipasi dengan menghitung kewajiban yang harus dibayar menggunakan rasio ini, karena jika kewajiban gagal untuk dilunasi dapat menyebabkan kebangkrutan pada perusahaan. Untuk dapat memenuhi kewajibannya, maka perusahaan harus mempunyai alat-alat untuk membayar yang berupa asset lancer yang jumlahnya harus jauh lebih besar daripada kewajiban yang harus dibayar oleh perusahaan.

Rasio likuiditas dapat dihitung menggunakan rasio kas (Cash Ratio). Cash Ratio adalah perbandingan yang dilakukan antara kas atau setara kas dengan utang lancar perusahaan. Rasio kas dapat dirumuskan sebagai berikut:

$$
\text { Cash Ratio }=\frac{\text { Kas }+ \text { Setara Kas }}{\text { Hutang Lancar }} \times 100 \%
$$

Menurut Kasmir (2014:143) ratarata industri untuk Cash Ratio adalah 0,5 kali atau $50 \%$. Kondisi perusahaan dapat dikatakan kurang baik jika Cash Ratio perusahaan kurang dari rata-rata industri yaitu dibawah 50\%. Kondisi ini dapat dikatakan perusahaan memerlukan waktu untuk menjual sebagian dari aset perusahaan dan membutuhkan waktu yang lama untuk membayar kewajibannya.

\section{Rasio Profitabilitas}

Rasio yang dihitung untuk melihat pemanfaatan sumber daya dari perusahaan seperti kas perusahaan, modal yang dimiliki dan sebagainya yang digunakan untuk mencari laba. Tujuan dan manfaat dari rasio ini adalah dapat melihat laba yang diperoleh perusahaan dengan melihat perkembangannya dari satu periode ke periode selanjutnya, dapat melihat dana perusahaan serta modal perusahaan digunakan dengan maksimal. Tingkat profitabilitas perusahaan dapat dihitung dengan menggunakan rasio margin laba bersih (Net Profit Margin). Kinerja perusahaan akan semakin baik jika margin laba bersih juga meningkat sehingga kepercayaan investor terhadap perusahaan akan ikut 
meningkat. Selain itu, kemampuan perusahaan dalam menekan biayabiaya perusahaan dapat dilihat dari margin laba bersih perusahaan sendiri. Net Profit Margin $=\frac{\text { Laba Bersih }}{\text { Penjualan Bersih }} \times 100 \%$

Laba bersih dapat dihitung dengan hasil pengurangan antara laba sebelum pajak penghasilan (laba operasional ditambah dengan pendapatan dan keuntungan lainnya) dengan beban pajak penghasilan. Pendapatan adalah arus masuk bruto yang timbul dari aktivitas normal perusahaan selama suatu periode bila arus masuk tersebut mengakibatkan kenaikan ekuitas yang tidak berasal dari kontribusi penanaman modal.

Laba perusahaan yang tinggi dapat digambarkan melalui profit margin yang tinggi pula pada waktu tertentu. Begitupun sebaliknya, jika profit margin rendah mencerminkan biaya yang tinggi pada operasional perusahaan dan tingkat penjualan yang terlalu rendah. Jika tingkat laba bersih semakin tinggi makan rasionya akan semakin baik, dan menunjukkan bahwa perusahaan dapat menghasilkan laba pada tingkat penjualan tertentu. Net Profit Margin memiliki standar industri yaitu 20\% (Kasmir 2014:208).

\section{Pertumbuhan Penjualan (Sales Growth)}

Baik buruknya tingkat pertumbuhan suatu perusahaan dapat diukur dengan pertumbuhan penjualan (sales growth) dari periode satu ke periode lainnya. Dengan mengetahui seberapa besar pertumbuhan penjualan, perusahaan dapat memprediksi seberapa besar profit yang akan didapatkan. Menurut Kasmir (2014: 107) "sales growth menggambarkan kemampuan perusahaan mempertahankan posisi ekonominya ditengah pertumbuhan perekonomian". Perusahaan perlu untuk dapat diterima di pasar agar produk atau jasa yang dihasilkan dapat diterima oleh konsumen. Maka dari itu, salah satu indikator yang penting untuk perusahaan adalah pertumbuhan atas penjualan, yang mana tingkat pertumbuhan penjualan dapat diukur melalui hasil penjualan yang didapatkan. Kondisi perusahaan atau profitabilitas perusahaan pada masa nanti, dapat dilihat dari perubahan penjualan perusahaan setiap tahunnya disebut dengan Sales growth (pertumbuhan penjualan). Kinerja perusahaan akan semakin membaik jika tingkat profitabilitas perusahaan meningkat dan itu disebabkan oleh pertumbuhan penjualan perusahaan meningkat. Dengan tingkat profitabilitas yang membaik, maka kemungkinan laba yang diperoleh perusahaan dapat membuat peningkatan penjualan bertumbuh dari kurun waktu tertentu. Perusahaan yang pertumbuhannya pesat cenderung lebih banyak menggunakan utang dari pada perusahaan yang pertumbuhannya lambat.

Sales Growth $=\frac{\text { Penjualan }(\mathrm{t})-\text { Penjualan }\left(\mathrm{t}_{1}\right)}{\text { Penjualan }\left(\mathrm{t}_{-1}\right)} \times 100 \%$

$\begin{array}{ll}\text { Ket : } & (\mathrm{t})=\text { penjualan pada tahun tertentu } \\ & (\mathrm{t}-1)=\text { penjualan pada periode sebelumnya }\end{array}$ 


\section{Kerangka Konseptual}

Gambar 4. Kerangka Konseptual

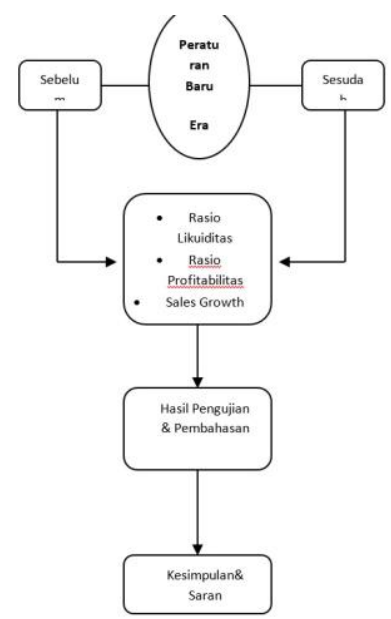

\section{METODE PENELITIAN}

Teknik analisis yang digunakan dalam penelitian ini yaitu pendekatan Event Study yang merupakan studi dengan pembahasan adanya suatu peristiwa yang baru terjadi. Dengan pemerintah yang mengeluarkan peraturan baru di awal tahun 2014 yang berupa Undangundang tentang Penyelenggaraan Jaminan Kesehatan Nasional merupakan peristiwa yang akan dibahas dalam penelitian ini.

Teknik analisis data pada penelitian ini yaitu menggunakan metode penelitian deskriptif kuantitatif dengan alat analisis perbandingan rasio keuangan yaitu rasio likuiditas yang dihitung melalui cash ratio, rasio profitabilitas yang dihitung melalui net profit margin dan sales growth. Data sekunder yang diberikan oleh pihak ketiga berbentuk dokumen yaitu laporan keuangan perusahaan berbentuk laporan neraca dan laporan laba rugi PT Hexpharm Jaya Laboratories dari tahun 2009-2013 dan 2014-2018. 


\section{HASIL PENELITIAN DAN PEMBAHASAN}

\section{Rasio Likuiditas}

Pada penelitian ini, rasio likuiditas dihitung dengan cash ratio sebagai berikut.

\begin{tabular}{|c|c|c|c|}
\hline Tahun & $\begin{array}{c}\text { Kas+Setara } \\
\text { Kas } \\
\text { (Rp) (a) }\end{array}$ & Utang Lancar & $\begin{array}{c}\text { Cash } \\
\text { Ratio } \\
\text { (c) }= \\
\text { (a) } /(\mathbf{b})\end{array}$ \\
\hline 2009 & $15,322,997,637$ & $44,904,944,478$ & $34,12 \%$ \\
\hline 2010 & $29,848,311,978$ & $45,076,954,380$ & $66,22 \%$ \\
\hline 2011 & $49,556,380,054$ & $52,694,428,529$ & $94,04 \%$ \\
\hline 2012 & $22,121,058,772$ & $64,512,908,881$ & $34,29 \%$ \\
\hline 2013 & $15,630,752,349$ & $68,121,307,432$ & $22,95 \%$ \\
\hline
\end{tabular}

\section{(Era Sebelum JKN)}

Tabel 1. Hasil Analisis perhitungan Cash Ratio

\section{(Pasca Era JKN)}

\begin{tabular}{|c|c|c|c|}
\hline Tahun & $\begin{array}{c}\text { Kas+Setara Kas } \\
(\mathbf{R p})(\mathbf{a})\end{array}$ & Utang Lancar & $\begin{array}{c}\text { Cash } \\
\text { Ratio } \\
(\mathbf{c})= \\
(\mathbf{R p})(\mathbf{b})\end{array}$ \\
\hline 2014 & $8,180,816,542$ & $100,815,799,488$ & $8,11 \%$ \\
\hline 2015 & $2,443,942,142$ & $113,215,367,423$ & $2,16 \%$ \\
\hline 2016 & $32,575,247,704$ & $87,495,576,530$ & $37,23 \%$ \\
\hline 2017 & $84,614,502,748$ & $154,993,650,599$ & $54,59 \%$ \\
\hline 2018 & $43,076,824,274$ & $179,561,425,155$ & $23,99 \%$ \\
\hline
\end{tabular}

Copyright (c) 2021 Stevany Febreany Rumapea, SE., M.Ak.
Tabel 2. Hasil Analisis perhitungan Cash Ratio

Perusahaan dapat dikatakan memiliki cash ratio yang baik jika hasil cash ratio setara dengan standar industri yaitu 50\%. Rata-rata pada periode pra JKN 2009-2018 diperoleh $50,32 \%$. Dapat disimpulkan rasio kas pada pra JKN diatas standar industri, sedangkan ratarata dari tahun 2014-2018 rasio kas perusahaan pada pasca era $\mathrm{JKN}$ adalah $25,21 \%$ yang mana dibawah dari standar industri.

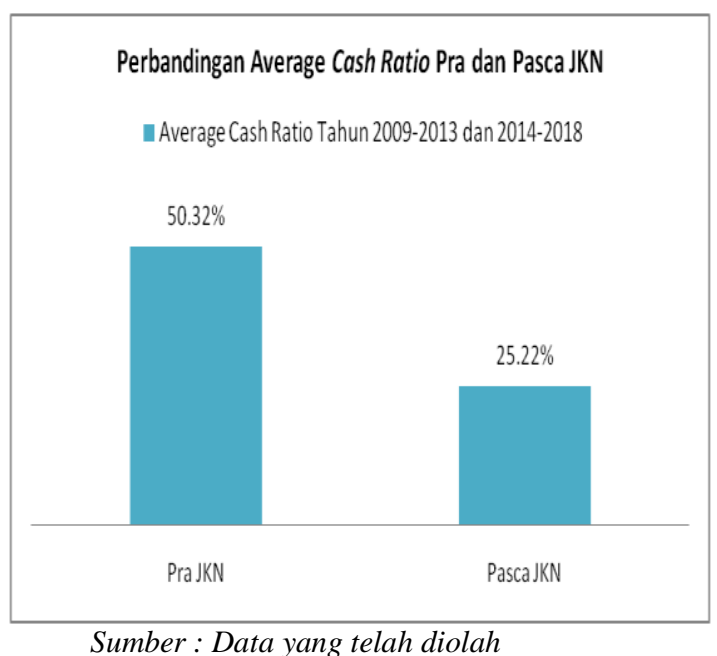

Gambar 5. Perbandingan grafik average cash ratio sebelum dan pasca JKN

Hasil pengujian rasio kas atau cash ratio pada era sebelum JKN dari tahun 2009-2013 dapat dikatakan sangat baik karena melampaui standar industri yang telah ditetapkan dan menggambarkan bahwa perusahaan dapat menutupi kewajiban jangka pendek yang perusahaan miliki.

Ketika ada permintaan dana untuk dicairkan dengan cepat atau ada kebutuhan mendesak yang mengharuskan pengeluaran dana dilakukan saat itu juga maka pada era sebelum Jaminan Kesehatan Nasional dapat memenuhi kebutuhan tersebut tetapi saat pasca 
Jaminan Kesehatan Nasional perusahaan tidak dapat memenuhi

kebutuhan tersebut karena cash ratio yang dimiliki rendah.

Cash ratio berhubungan dengan cash flow yang dimiliki perusahaan. Laporan arus kas sangat penting untuk dimiliki perusahaan karena pihak manajemen perusahaan dapat melihat dan mengontrol kas masuk dan kas keluar perusahaan yang akan mempengaruhi pembayaran dividen yang dilakukan perusahaan dan kewajiban-kewajiban seperti pembayaran bunga, pinjaman terhadap bank, atau kreditur lainnya. Pada era pra Jaminan Kesehatan Nasional terlihat bahwa perusahaan memiliki cadangan kas yang tinggi untuk membayar semua kewajiban jangka pendeknya karena dengan cash ratio yang tinggi maka dapat menggambarkan cadangan kas perusahaan ikut tinggi. Berbeda dengan pada era pasca Jaminan Kesehatan Nasional, cash ratio yang diperoleh lebih rendah dari pra JKN yang menggambarkan bahwa perusahaan memiliki cadangan kas yang rendah.

Dari hasil pengujian diatas dapat disimpulkan bahwa total liabilitas pada era pasca Jaminan Ksehatan Nasional pada tahun 2014-2018 semakin meningkat dengan signifikan dari era sebelum Jaminan Kesehatan Nasional pada tahun 2009-2013. Dengan total liabilitas perusahaan yang meningkat, tetapi tidak diiringi dengan kenaikan pada kas perusahaan dan menyebabkan cash ratio menjadi rendah. Hasil dari penelitian ini adalah Jaminan Kesehatan Nasional berpengaruh terhadap rasio likuiditas terlihat dari hasil perhitungan, rasio kas menurun saat adanya kebijakan pemerintah baru.

\section{Rasio Profitabilitas}

Rasio profitabilitas penelitian ini dihitung dengan rasio margin laba bersih atau Net Profit Margin. Jika NPM tinggi maka semakin baik operasi dari suatu perusahaan.

\section{(Era Sebelum JKN)}

\begin{tabular}{|c|c|c|c|}
\hline Tahun & $\begin{array}{c}\text { Laba Bersih } \\
(\mathbf{R p})(\mathbf{a})\end{array}$ & Penjualan & $\begin{array}{c}\text { NPM } \\
\text { Ratio } \\
(\mathbf{c})= \\
(\mathbf{a}) /(\mathbf{b})\end{array}$ \\
\hline 2009 & $39,414,599,879$ & $346,715,220,929$ & $11,37 \%$ \\
\hline 2010 & $56,824,834,543$ & $398,179,827,470$ & $14,27 \%$ \\
\hline 2011 & $65,247,463,157$ & $429,641,023,190$ & $15,19 \%$ \\
\hline 2012 & $59,935,220,620$ & $548,613,907,876$ & $10,92 \%$ \\
\hline 2013 & $55,186,075,784$ & $650,734,682,406$ & $8,48 \%$ \\
\hline
\end{tabular}

Tabel 3. Hasil Analisis Rasio perhitungan Net Profit Margin Ratio

(Pasca Era JKN)

\begin{tabular}{|c|c|c|c|}
\hline Tahun & Laba Bersih & Penjualan & $\begin{array}{c}\text { NPM } \\
\text { Ratio } \\
(\mathbf{c})= \\
(\mathbf{a}) /(\mathbf{b})\end{array}$ \\
\hline 2014 & $44,417,331,696$ & $729,854,164,535$ & $6,09 \%$ \\
\hline 2015 & $21,633,887,588$ & $724,640,054,682$ & $2,99 \%$ \\
\hline 2016 & $46,908,075,847$ & $865,676,432,754$ & $5,42 \%$ \\
\hline 2017 & $71,399,811,026$ & $1,025,926,816,127$ & $6,96 \%$ \\
\hline 2018 & $66,986,810,064$ & $1,132,288,216,773$ & $5,92 \%$ \\
\hline
\end{tabular}

Tabel 4. Hasil Analisis perhitungan Net Profit Margin Ratio

Perusahaan dapat dikatakan memiliki net profit margin yang baik jika hasil net profit margin setara atau lebih dari standar industri yaitu 20\%. Pada tahun 2009-2018 baik era pra JKN maupun pada pasca era JKN hasil 
perhitungannya masih dibawah standar industri bahkan pada pasca era JKN lebih menurun dibanding pada era pra JKN.

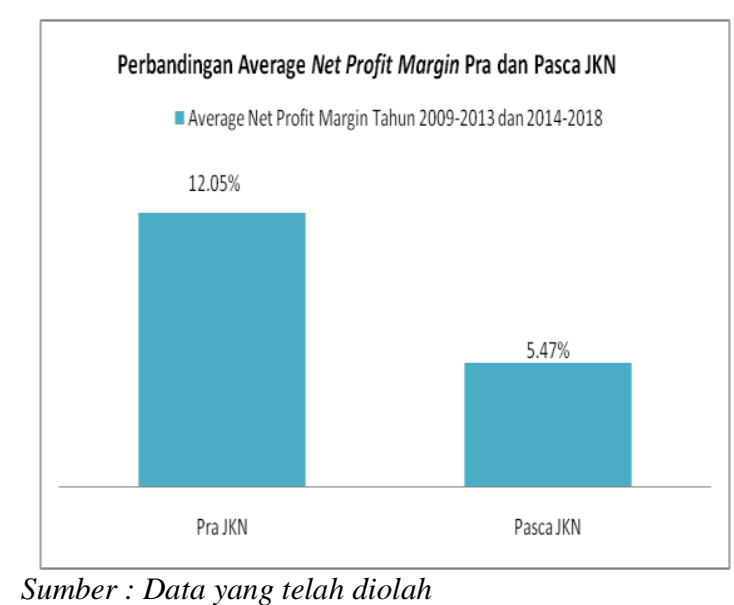

Gambar 6 Perbandingan grafik average net profit margin era sebelum dan pasca JKN

Hasil pengujian net profit margin pada era sebelum JKN dari tahun 2009-2013 dapat dikatakan cukup baik walaupun tidak melampaui standar industri yang telah ditetapkan. Dapat diartikan bahwa pihak manajemen PT Hexpharm Jaya Laboratories pada era pra Jaminan Kesehatan Nasional dapat mengelola biaya operasional perusahaan dengan efisien dibandingkan dengan hasil pengujian net profit margin pada era pasca JKN dari tahun 2014-2018. Karena, net profit margin pada pasca JKN lebih rendah dibanding era sebelum JKN yang disebabkan dengan beban operasional yang meningkat.

Dapat diartikan pada era sebelum Jaminan Kesehatan Nasional, manajemen perusahaan belum dapat mengelola biaya-biaya operasional perusahaan dengan baik dan itu berpengaruh terhadap profitabilitas perusahaan yaitu profit perusahaan atau laba bersih perusahaan. Makin besar margin laba bersih yang diperoleh maka kinerja perusahaan akan semakin baik dan akan membuat para investor perusahaan semakin yakin untuk menginvestasikan sebagian hartanya kepada perusahaan. Jika net profit margin yang diperoleh semakin kecil maka kemungkinan perusahaan akan merugi.

Apabila net profit margin (NPM) perusaahaan meningkat, maka perusahaan digambarkan dapat mengendalikan harga pokok barang, beban operasional, pajak, bunga pinjaman dari bank secara efektif dan efisien. Ketika perusahaan dapat mengelola Harga pokok barangnya dengan baik maka perusahaan dapat mengetahui biaya-biaya yang dikeluarkan untuk menjual 1 (satu) unit produk dan menggambarkan keuntungan yang dapat diperoleh dengan menjual 1 (satu) produk tersebut.

Dengan net profit margin yang meningkat dan berpengaruh pada kemampuan perusahaan pada pengendalian harga pokok barang maka perusahaan dapat membuat rencana pengendalian dan perencanaan yang matang atas target pasar penjualan untuk produk yang dihasilkan sehingga setiap tahunnya perusahaan dapat mencapai profitabilitas yang baik. Ketika net profit margin meningkat, maka perusahaan dapat membayaran kewajiban perusahaan seperti pajak dan bunga pinjaman dari pihak ketiga secara tepat waktu sehingga bunga yang diperoleh perusahaan tidak semakin meningkat. Artinya bahwa pada era sebelum Jaminan Kesehatan Nasional perusahaan akan menghasilkan laba dengan cukup tinggi dibandingkan dengan setelah berlakunya Undang-undang Jaminan Kesehatan Nasional.

\section{Pertumbuhan Penjualan (Sales Growth)}

Jumlah penjualan perusahaan yang mengalami kenaikan dari tahun ke tahun disebut juga pertumbuhan penjualan (Sales Growth). 
(Pra Era JKN)

\begin{tabular}{|c|c|c|c|}
\hline Tahun & Penjualan (t) & Perubahan & $\begin{array}{c}\text { Sales } \\
\text { Growth } \\
(\mathrm{c})=(\mathrm{a}- \\
\mathrm{b}) / \mathrm{b}\end{array}$ \\
\hline 2009 & $346,715,220,929$ & - & \\
\hline 2010 & $398,179,827,470$ & $51,464,606,541$ & $14.84 \%$ \\
\hline 2011 & $429,641,023,190$ & $31,461,195,720$ & $7.90 \%$ \\
\hline 2012 & $548,613,907,876$ & $118,972,884,686$ & $27.69 \%$ \\
\hline 2013 & $650,734,682,406$ & $102,120,774,530$ & $18.61 \%$ \\
\hline
\end{tabular}

Tabel 5. Hasil Analisis Pertumbuhan Penjualan

\section{(Pasca Era JKN)}

\begin{tabular}{|c|c|c|c|}
\hline Tahun & Penjualan (t) & Perubahan & $\begin{array}{c}\text { Sales } \\
\text { Growth } \\
(\mathbf{c})=(\mathbf{a}- \\
\mathbf{b}) / \mathbf{b}\end{array}$ \\
\hline 2014 & $729,854,164,535$ & $79,119,482,129$ & $12.16 \%$ \\
\hline 2015 & $724,640,054,082$ & $-5,214,110,453$ & $-0.71 \%$ \\
\hline 2016 & $865,676,432,754$ & $141,036,378,672$ & $19.46 \%$ \\
\hline 2017 & $1,025,926,816,127$ & $160,250,383,373$ & $18.51 \%$ \\
\hline 2018 & $1,132,288,216,773$ & $106,361,400,646$ & $10.37 \%$ \\
\hline
\end{tabular}

Tabel 6. Hasil Analisis Pertumbuhan Penjualan
Hasil penelitian ini menggambarkan sales setiap tahunnya meningkat baik era pra Jaminan Kesehatan Nasional maupun pasca Jaminan Kesehatan Nasional. Pada pra era jaminan kesehatan nasional, pada tahun 2009 penjualan sekitar 346 milyar, naik pada tahun 2010 sampai pada tahun 2013 terjadi kenaikan menjadi 650 milyar. Pada era pasca jaminan kesehatan nasional penjualan terus meningkat hingga mencapai jumlah penjualan 729 milyar di tahun 2014 dan 1,132 triliun pada tahun 2018.

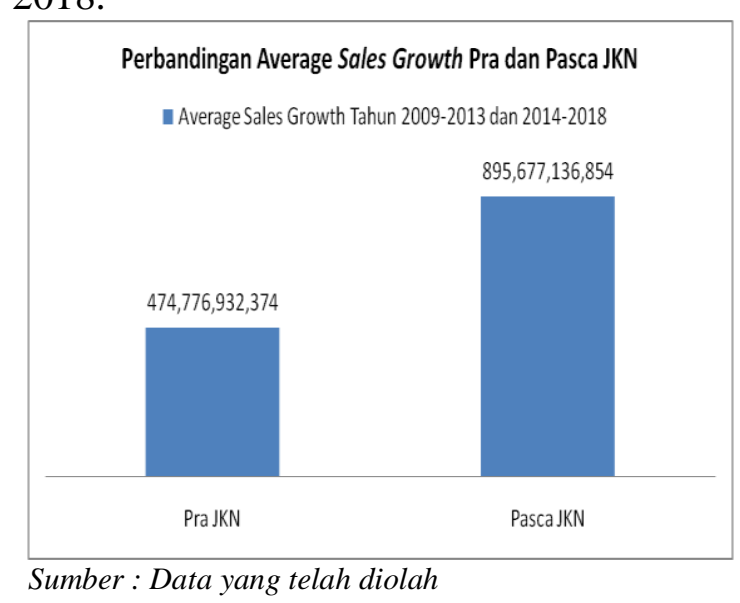

Gambar 7 Perbandingan grafik average cash ratio era sebelum dan pasca JKN

Hasil pengujian sales growth pada era pra JKN dari tahun 2009-2013 dapat disimpulkan baik, karena setiap tahun mengalami kenaikan penjualan. Dapat diartikan bahwa PT Hexpharm Jaya Laboratories sebelum era JKN dapat mempertahankan dan meningkatkan permintaan produk yang dihasilkan dipasar obat dan meningkatkan kekuatan perusahaan dalam daya saing perusahaan.

Dengan pertumbuhan penjualan yang pesat pada pra JKN maka terlihat perusahaan dapat meemperoleh keberhasilan pertumbuhan penjualan yang semakin meningkat di masa depan yaitu pada era pasca JKN. Hasil pengujian sales growth pada pasca JKN dari tahun 2014-2018 dapat dikatakan lebih baik 
dari era pra JKN diikuti dengan kenaikan jumlah penduduk Indonesia dan kebutuhan masyarakat akan obat serta pedulinya masyarakat akan kesehatan.

Terlihat rata-rata penjualan sebelum dan sesudah era JKN pertumbuhan penjualan meningkat sekitar $100 \%$. Dengan peningkatan penjualan yang diperoleh perusahaan maka pendapatan perusahaan akan ikut meningkat pada masa yang akan datang dan berpengaruh terhdap peningkatan deviden yang diberikan. Dengan kenaikan pertumbuhan penjualan pada pasca JKN maka penerimaan pasar juga menjadi lebih baik terhdapa produk yang kita hasilkan dibandingkan dengan pra JKN. Maka dari itu, sangat berpengaruh terhdapat jumlah dan volume produk yang dijual serta perusahaan harus memiliki strategi agar perusahaan tetap selalu di terima baik di pasar obat sehingga konsumen selalu memilih produknya. Karena perusahaan yang menjual produk dalam jumlah dan volume yang besar akan mempengaruhi laba yang diterima. Dengan laba yang ditperoleh perusahaan dari tahun ke tahun terus meningkat maka investor perusahaan pun akan ikut meningkat.

Pertumbuhan penjualan juga berhubungan dengan strategi yang telah dibuat oleh perusahaan. Pertumbuhan penjualan PT Hexpharm Jaya terus meningkat dari tahun 2009-2018 dan itu menggambarkan strategi yang dimiliki oleh perusahaan dapat berjalan dengan baik dan dapat dicapai dengan maksimal. Selain itu, pertumbuhan penjualan dapat menggambarkan prospek perusahaan pada masa yang akan datang. Maka dari itu, dengan meningkatnya pertumbuhan penjualan PT Hexpharm Jaya Laboratories dapat dikatakan prospek perusahaan baik pada masa yang akan datang.

Hal ini mendukung dengan hasil penelitian sebelumnya terkait pertumbuhan penjualan sebelum dan sesudah implementasi Jaminan Kesehatan Nasional. Penelitian ini dilakukan oleh Rina Wahyu Wijayani, hasil penelitian mencerminkan pendapatan mengalami peningkatan setiap tahunnya yang dihitung secara rata-rata dari 31 RS Vertikal Kementerian Kesehatan dan hasil dari penelitian dari Rina Wahyu Wijayani sesuai dengan hasil penelitian ini yaitu terjadi peningkatan rata-rata pertumbuhan penjualan setelah implementasi Jaminan Kesehatan Nasional.

\section{KESIMPULAN DAN SARAN}

\section{Kesimpulan}

Berdasarkan hasil analisis yang telah diteliti diambil kesimpulan sebagai berikut:

1. Dari analisis rasio likuiditas maka kinerja keuangan PT Hexpharm Jaya Laboratories lebih baik pada saat era Pra JKN yaitu pada tahun 2009-2013 dibanding dengan era Pasca JKN yaitu pada tahun 20142018. Hal tersebut terjadi disebabkan defisitnya Badan Penyelenggara Jaminan Sosial (BPJS) yang menyebabkan proses pembayaran rumah sakit ke perusahaan menjadi terhambat atau tidak tepat waktu dan akan berdampak pada cash flow perusahaan khususnya perusahaan farmasi yang akan memengaruhi produksi obat. Perusahaan lebih siap membayar utang jangka pendek dengan cepat pada saat pra JKN yaitu tahun 2009-2013 dibandingkan dengan Pasca JKN tahun 2014-2018 karena perusahaan lebih memiliki cadangan kas yang tinggi saat sebelum implementasi jaminan kesehatan nasional dibanding sesudah implementasi.

2. Analisis rasio profitabilitas menyimpulkan kinerja keuangan PT Hexpharm Jaya Laboratories lebih baik pada saat era Pra JKN walaupun laba perusahaan belum maksimal. Hal tersebut terjadi karena harga jual obat generik yang ditetapkan pemerintah dibawah biaya produksi yang menyebabkan keuntungan perusahaan 
menipis, dan perusahaan farmasi harus beroperasi dengan sistem "low price and low margin". Dengan demikian, laba bersih yang diperoleh Perusahaan masih belum maksimal tetapi lebih besar saat era Pra JKN yaitu tahun 2009-2013 dibandingkan Pasca JKN yaitu tahun 2014-2018.

3. Jika dilihat dari analisis pertumbuhan penjualan (sales growth), maka Era Jaminan Kesehatan Nasional cukup baik untuk pertumbuhan penjualan pada PT Hexpharm Jaya Laboratories tahun 20092018. Dengan kata lain, dapat disimpulkan bahwa Era Jaminan Kesehatan Nasional memberi dampak baik terhadap pertumbuhan penjualan yang diikuti dengan keingintahuan masyarakat akan kesehatan dan melonjaknya pertumbuhan masyarakat Indonesia, serta kemudahan dalam akses obat-obatan.

\section{Saran}

Perusahaan harus memiliki pengendalian terhadap cash flow baik itu inflow maupun outflow yang dapat digunakan untuk memonitoring uang kas perusahaan supaya kondisi kas perusahaan selalu termonitoring dan mencukupi untuk menutup pengeluaran yang terjadi diperusahaan. Peneliti menyarankan agar peneliti selanjutnya dapat menggunakan sampel perusahaan farmasi atau perusahaan lainnya yang lebih banyak agar dapat dibandingkan antara perusahaan satu dengan perusahaan lainnya sehingga mendapatkan hasil yang lebih kompleks dan akurat serta dengan menggunakan perhitungan rasio yang berbeda atau dengan perhitungan rasio yang lebih banyak dari penelitian saat ini agar dapat menggambarkan kinerja keuangan dengan maksimal.

\section{DAFTAR PUSTAKA}

Anggriani, Yusi., Sarnianto, Prih., Aisyah, Siti., Pontoan, Jenny. (2017). Analisis Trend Harga Obat Sebelum dan Sesudah Penerapan E-catalogue di Rumah Sakit, Jurnal, Jakarta: Universitas Pancasila, Jakarta: Institut Sains dan Teknologi Nasional

Aziz, Royan, (2014), Pengertian Net Profit Margin (NPM), (ONLINE), https://www.seputarforex.com/

Badan Penyelenggara Jaminan Sosial. (2019). Defisit BPJS Kesehatan 2014-2019, (ONLINE), https://databoks.katadata.co.id/

Depkes RI. (2013b). Peraturan Menteri Kesehatan Nomor 48 Tahun 2013 tentang petunjuk pelaksanaan pengadaan obat dengan prosedur e-purchasing berdasarkan e-catalogue. Jakarta: Departemen Kesehatan Republik Indonesia

Hery. (2017). Teori Akuntansi Pendekatan Konsep dan Analisis. Jakarta: PT. Grasindo

Jaminan Kesehatan Nasional, Pusat Pembiayaan Pusat Pembiayaan dan Jaminan Kesehatan Sekretariat Jenderal Kementerian Kesehatan RI, (ONLINE), www.jkn.kemkes.go.id/

Kasmir. (2014). Analisis Laporan Keuangan. Cetakan ke-7. PT Rajawali Grafindo Persada, Jakarta

Kristiyanto, Fransiskus Asisis Verry , (2013), Landasan Teori Tingkat Pertumbuhan Penjualan, (ONLINE), Available, http://asisiverry.blogspot.com/

Madina, Muhammad Farham. (2017). Analisis Kinerja Keuangan Perusahaan Asuransi di Indonesia Sebelum dan Sesudah Adanya Undang-Undang Badan Penyelenggara Jaminan Sosial. Jurnal Surabaya: Universitas Negeri Surabaya. 
Mutiarin, Dyah \& Kesmawan, Andri Putra. (2014). Implementasi Kebijakan Badan Penyelenggara Jaminan Sosial (Bpjs) Kesehatan di Kabupaten Bantul Daerah Istimewa Yogyakarta. Jurnal Ilmu Pemerintahan \& Kebijakan Publik.

Nuraini, Ani., Ismaya, Brata, Sakti., Piguno Amrih., \& Baharudin, Agus. (2019). Is The Financial Performance Of Insurance Companies Listed In Idx Able To Make Profitability After The Existence Of BPJS?, Healthy and Active Ageing.

Suhartiyas, Yuyun. (2017). Analisis

Kesehatan Keuangan Berdasarkan Rasio Likuiditas Dan Rasio Profitabilitas Dalam Implementasi Jaminan Kesehatan Nasional Pada Rs.X Mojokerto. The Indonesian Journal of Health Science.

Undang-Undang Republik Indonesia nomor 24 Tahun 2011 tentang Badan Penyelenggara Jaminan Sosial.

Undang-Undang Dasar 1945 Pasal 28 H ayat 1 tentang Pemeliharaan Kesehatan.

Undang-Undang Dasar 1945 Pasal 34 ayat 3 tentang Penyediaan Fasilitas Pelayanan Kesehatan.

Undang-Undang No.40 Tahun 2004 tentang Sistem Jaminan Sosial Nasional

Wijayani, Rina Wahyu. (2018. Dampak Implementasi Program Jaminan Kesehatan Nasional (JKN) Terhadap Kinerja Keuangan Rumah Sakit Vertikal Kementerian Kesehatan. Jurnal Kebijakan Kesehatan Indonesia : JKKI, Vol. 7

Wild Jhon J., Subramanyam K.R., Hasley Robert F, (Yasivi S. Bachtiar, S.Nurwahyu Harahap), (2005). Analisis Laporan Keuangan, Edisi kedelapan, Jakarta: Salemba Empat.

Yusriadi. (2019). Public Health Services: A Case Study on BPJS in Indonesia. Jurnal Administrasi Publik (Public Administration Journal). 